University of Nebraska - Lincoln

DigitalCommons@University of Nebraska - Lincoln

Faculty Publications from the Harold W. Manter Laboratory of Parasitology

6-2009

Robustostrongylus aferensis gen. nov. et sp. nov. (Nematoda: Trichostrongyloidea) in Kob (Kobus kob) and Hartebeest (Alcelaphus buselaphus jacksoni) (Artiodactyla) from Subsaharan Africa, with Further Ruminations on the Ostertagiinae

Eric P. Hoberg

United States Department of Agriculture, eric.hoberg@ars.usda.gov

Arthur Abrams

United States Department of Agriculture

Patricia A. Pilitt

United States Department of Agriculture

Follow this and additional works at: https://digitalcommons.unl.edu/parasitologyfacpubs

Part of the Parasitology Commons

Hoberg, Eric P.; Abrams, Arthur; and Pilitt, Patricia A., "Robustostrongylus aferensis gen. nov. et sp. nov. (Nematoda: Trichostrongyloidea) in Kob (Kobus kob) and Hartebeest (Alcelaphus buselaphus jacksoni) (Artiodactyla) from Sub-saharan Africa, with Further Ruminations on the Ostertagiinae" (2009). Faculty Publications from the Harold W. Manter Laboratory of Parasitology. 322.

https://digitalcommons.unl.edu/parasitologyfacpubs/322

This Article is brought to you for free and open access by the Parasitology, Harold W. Manter Laboratory of at DigitalCommons@University of Nebraska - Lincoln. It has been accepted for inclusion in Faculty Publications from the Harold W. Manter Laboratory of Parasitology by an authorized administrator of DigitalCommons@University of Nebraska - Lincoln. 


\title{
ROBUSTOSTRONGYLUS AFERENSIS GEN. NOV. ET SP. NOV. (NEMATODA: TRICHOSTRONGYLOIDEA) IN KOB (KOBUS KOB) AND HARTEBEEST (ALCELAPHUS BUSELAPHUS JACKSONI) (ARTIODACTYLA) FROM SUB-SAHARAN AFRICA, WITH FURTHER RUMINATIONS ON THE OSTERTAGIINAE
}

\author{
Eric P. Hoberg, Arthur Abrams, and Patricia A. Pilitt \\ United States National Parasite Collection and Animal Parasitic Disease Laboratory, United States Department of Agriculture, Agricultural \\ Research Service, BARC East, Building 1180, 10300 Baltimore Avenue, Beltsville, Maryland 20705. e-mail: eric.hoberg@ars.usda.gov
}

\begin{abstract}
Abomasal nematodes (Ostertagiinae: Trichostrongyloidea), representing a previously unrecognized genus and species, were discovered in kob (Kobus kob) and kongoni (hartebeest) (Alcelaphus buselaphus jacksoni) from Uganda during surveys of ungulate parasites in the 1960s. Robustostrongylus aferensis gen. nov. et sp. nov. is characterized by a ventriculus-like, bilobed valve at the junction of the esophagus and intestine, a synlophe with unusually robust ridges, cervical papillae and excretory pore situated posterior to the mid-length of the esophagus, a unique body form and large diameter in males and females, a relatively anterior position for the vulva, and strongly convoluted and spiraled ovarian tracks in females. Bursal structure is 2-12 , with subequal Rays $2 / 3$, strongly reduced and robust Rays 8 , and relatively narrow Rays $9 / 10$ contained within a reduced, laterally inflated dorsal lobe. Spicules are filamentous and tripartite; the gubernaculum is cryptic, alate, and heart-shaped in the anterior. Robustostrongylus aferensis, with narrow filamentous spicules that trifurcate distally near $80 \%$, paired arcuate " 0 " papillae that terminate in bulbous expansions, and a reduced dorsal lobe and ray most closely resembles species of Longistrongylus. A suite of unique characters, consistent in males and females, however, unequivocally distinguishes specimens of $R$. aferensis from all ostertagiines with either a 2-1-2 or 2-2-1 bursal pattern. Among 15 genera of the Ostertagiinae in the global fauna, 5 are entirely limited in distribution to Africa, including Africanastrongylus, Hamulonema, Longistrongylus, Pseudomarshallagia, and Robustostrongylus gen. nov.; species among 5 additional genera, including Cervicaprastrongylus, Hyostrongylus, Marshallagia, Ostertagia, and Teladorsagia, also occur in Africa, but they are represented as mosaics, with diversity centered in Eurasia or the Holarctic.
\end{abstract}

Medium stomach worms in ungulates, usually referred to the Ostertagiinae (Trichostrongyloidea), remain economically important parasites among domestic and free-ranging livestock throughout the world. Diversity for this abomasal parasite fauna is relatively well defined for those nematodes occurring globally in cattle, sheep, goats, and some farmed cervids (Hoberg et al., 2001; Haigh et al., 2002), although accurate taxonomy continues to be hindered by confusion over the application of polymorphism among males representing single species (Dróżdż, 1995; Hoberg et al., 1999). Concepts for species-limits have also been changing in this group as a consequence of cryptic diversity revealed through molecular systematics combined with detailed comparative morphology (Criscione et al., 2005). Such is best exemplified within Teladorsagia Andreeva and Satubaldin, 1954 in which T. circumcincta (Stadelman, 1894) has been shown to include an array of cryptic species in domestic and free-ranging artiodactyls (Hoberg et al., 1999; Leignel et al., 2002; Grillo et al., 2007); the occurrence of species complexes is predicted to be a generality across other related genera among the ostertagiines but remains to be evaluated. An accurate definition of diversity, including reliable taxonomy encompassing morphological and molecular criteria extending to population genetics, in conjunction with comprehensive data for host and geographic distributions, are the cornerstones for understanding epizootiolgy and patterns of emerging disease across a mosaic of rapidly changing environments and for development of efficient and robust measures for control of parasitism in ungulates (Hoberg, 1997; Brooks and Hoberg, 2000, 2006, 2007; Hoberg, Polley et al., 2008).

Although the global fauna and its intricate structure of endemic and introduced species in most biogeographic regions is

Received 5 September 2008; revised 5 February 2009; accepted 12 February 2009.

DOI: $10.1645 / G E-1859.1$ becoming understood (Hoberg et al., 2004; Hoberg, Polley et al., 2008), previously unrecognized genera and species continue to be discovered, particularly in Africa (Hoberg and Abrams, 2008; Hoberg, Abrams, and Ezenwa, 2008). One third of known genera of ostertagiines are endemic to Africa; yet, comprehensive surveys for many species of ungulates have not been conducted, and parasitological examinations have often been based on relatively few hosts or have focused on relatively restricted geographic zones. Over the last century, however, considerable details of the African ostertagiine and trichostrongyloid fauna in both domestic and free-ranging ungulates have been revealed (e.g., Le Roux, 1931; Mönnig, 1932; Round, 1962, 1968; Sachs and Sachs, 1968; Gibbons, 1974, 1977); notable here are the substantial body of surveys and articles addressing parasite faunas among domestic and free-ranging ungulates from South Africa by J. Boomker, I. G. Horak, and their colleagues and from eastern Africa by L. M. Gibbons and L. F. Khalil (summarized in Hoberg, Abrams, and Ezenwa, 2008).

The global ostertagiine fauna currently encompasses 14 genera (Hoberg and Abrams, 2008); aspects of this proposed generic taxonomy adopt components of a diversity of opinions presented for these nematodes over the past $70 \mathrm{yr}$ (e.g., Travassos, 1937; Skrjabin et al., 1954; Andreeva, 1956; Dróżdż, 1965; Durette-Desset and Chabaud, 1981; Durette-Desset, 1982, 1983, 1989; Gibbons and Khalil, 1982; Jansen, 1989; Durette-Desset et al., 1999). Among the ostertagiines, 8 genera are characterized by males in which the lateral rays of the copulatory bursa describe a 2-2-1 pattern (defined by Durette-Desset and Chabaud, 1981; Durette-Desset, 1983). Specifically, these include Africanastrongylus Hoberg, Abrams and Ezenwa, 2008, Cervicaprastrongylus Gibbons and Khalil, 1982, Натиlonema Hoberg and Abrams, 2008, Hyostrongylus Hall, 1921, Mazamastrongylus Cameron, 1935, Sarwaria Dróżdż, 1965, Spiculopteragia (Orloff, 1933), and Teladorsagia (e.g., DuretteDesset, 1983; Gibbons and Khalil, 1982; Hoberg, Abrams, and 
TABLE I. Specimens of Robustostrongylus aferensis gen. nov. et sp. nov. and species of Longistrongylus and Pseudomarshallagia examined from Africa.

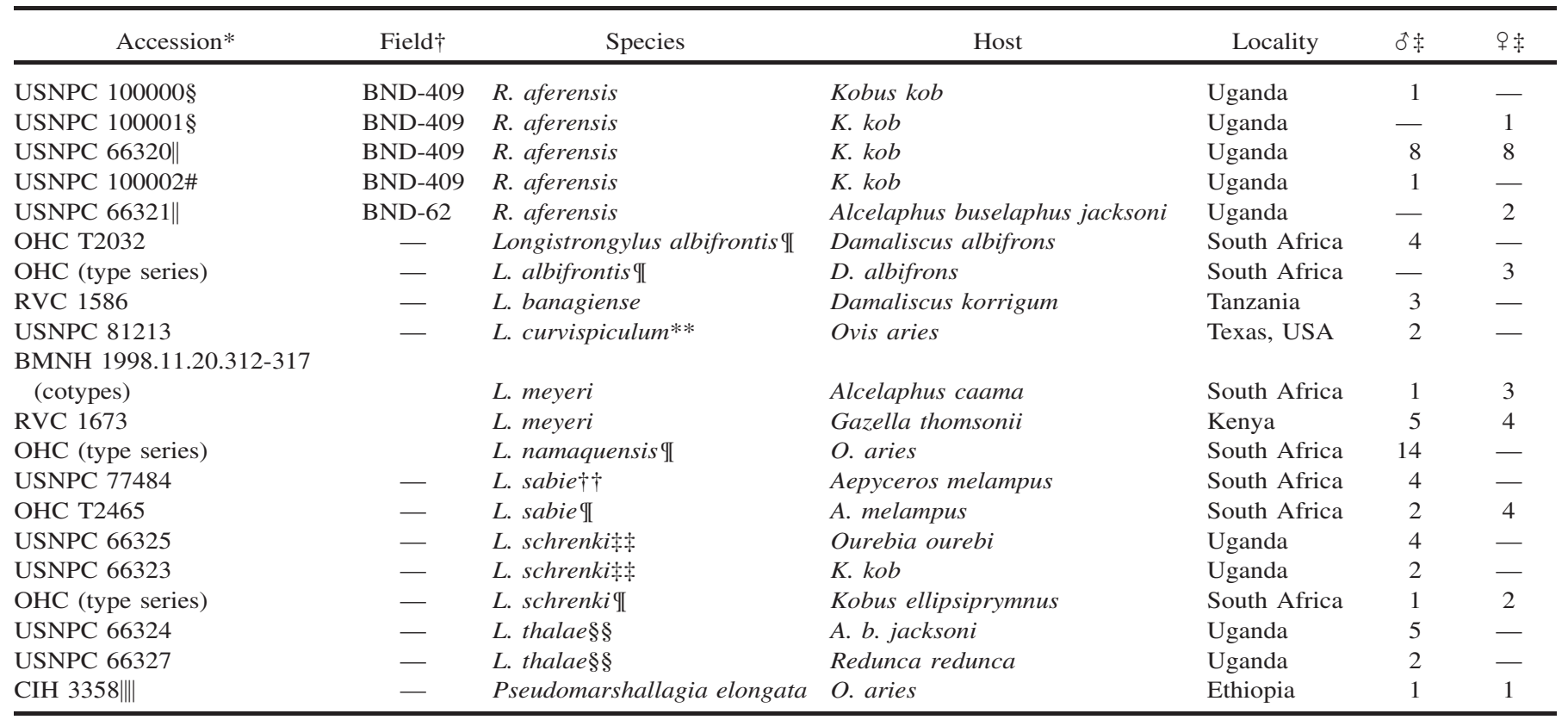

* Collection and specimen numbers from the U.S. National Parasite Collection (USNPC), the British Museum of Natural History (BMNH), the Onderstepoort Helminthological Collection (OHC), and the Royal Veterinary College (RVC). Collections of the RVC contain materials from Commonwealth Institute of Helminthology $(\mathrm{CIH})$.

$\leftarrow$ Field number at time of original collection.

$\doteqdot$ Number of male and female specimens examined.

$\S$ Holotype male and allotype female. Originally from collections by J. Bindernagle.

$\|$ Paratypes. Originally from collections by J. Bindernagle.

\# Voucher specimen.

II Morphological data and line drawings from the type specimens examined by W. W. Becklund and M .L. Walker (U.S. National Parasite Collection, unpublished documents). Numbers of specimens examined by WWB and MLW could not be reliably determined.

** Longistrongylus curvispiculum represents a species previously referred to Bigalkenema; material examined represent vouchers from an introduced population in western Texas (Craig, 1993) and was from an experimental infection in domestic sheep based on larvae recovered from Oryx biesa.

$\dagger \dagger$ Longistrongylus sabie are vouchers and represent a species previously referred to Bigalkenema.

t+Longistrongylus schrenki represents a species previously referred to Kobusinema. Specimens are vouchers from collections by J. Bindernagle.

$\$ \$$ Longistrongylus thalae represent voucher specimens from collections by J. Bindernagle.

||| Voucher specimens are represented by 4 permanent slides deposited by M. Graber and include a male specimen with detached bursa, dissected spicules, and 2 slides of cross sections showing the synlophe.

Ezenwa, 2008; Hoberg and Abrams, 2008). Among 6 remaining genera, a 2-1-2 bursal pattern is characteristic, being represented in species of Camelostrongylus Orloff, 1933, Longistrongylus Le Roux, 1931, Marshallagia (Orloff, 1933), Orloffia Dróżdż, 1965, Ostertagia Ransom, 1907, and Pseudomarshallagia (Roetti, 1941).

In the current study, we propose establishment of a new genus among the ostertagiines to accommodate unique nematodes in ungulates from eastern Africa originally collected by Dr. John Bindernagle during the 1960s. These specimens were initially examined by W. W. Becklund and M. L. Walker at the U.S. National Parasite Collection in the late 1960s and early 1970s, but definitive taxonomic decisions were not developed. Studies of materials in the Bindernagle Collections were reinitiated during broader investigations of the ostertagiines, which led to proposals for Africanastrongylus and Hamulonema (Hoberg and Abrams, 2008; Hoberg, Abrams, and Ezenwa, 2008). Here, we diagnose the remaining new generic-level taxon evident in these collections, and explore aspects of the history and distribution for ostertagiines in the African and global faunas.

\section{MATERIALS AND METHODS}

Specimens of a previously undescribed ostertagiine nematode included 10 males and 9 females in a kob, Kobus kob (Erxleben), and 2 females in a kongoni (hartebeest), Alcelaphus buselaphus jacksoni (Pallas), from Uganda collected by J. Bindernagle in 1964. All materials representing this unrecognized species and new genus are held in the U.S. National Parasite Collection, U.S. Department of Agriculture, Beltsville, Maryland (USNPC); specimens are held in vials in a solution of $70 \%$ ethanol with $4 \%$ formalin by volume.

As a basis for comparisons within the Ostertagiinae, specimens of Longistrongylus banagiense (Gibbons, 1972), L. curvispiculum (Gibbons, 1973), L. meyeri Le Roux, 1931, L. sabie (Mönnig, 1932), L. schrenki (Ortlepp, 1939), and L. thalae (Troncy and Graber, 1973) were examined. Observations, notes, and line drawings from morphological studies of the type specimens for L. albifrontis (Mönnig, 1931), L. namaquensis (Ortlepp, 1963), L. sabie, and L. schrenki by W. W. Becklund and M. L. Walker (U.S. National Parasite Collection, unpublished documents) were also used in our current evaluations. A male specimen of Pseudomarshallagia elongata (Roetti, 1941), permanently mounted in glycerine jelly; transverse sections; and dissected spicules were examined. Redescriptions of P. elongata Roetti, 1941 by Graber and Delavenay (1978), Gibbons (1981a), and Gibbons and Khalil (1982) were also used for comparisons because of the unavailability of the type specimens or larger series of vouchers for evaluation. Specimens and 
sources for species of ostertagiine nematodes used in comparative morphological studies are listed (Table I). Specimens of Haemonchinae from the USNPC used in the current study are listed in Hoberg et al. (2004). Additionally, multiple lots of Graphidium strigosum (Dujardin, 1845) from leporid hosts included USNPC 16895, 18065, and 66335. These latter specimens were necessary to establish the context for certain morphological attributes among the Ostertagiinae.

Nematodes were prepared as temporary whole mounts cleared in phenol-alcohol (80 parts melted phenol crystals and 20 parts absolute ethanol) and examined with interference contrast microscopy. The synlophe was studied in whole mounts, with particular attention to the pattern of ridge systems in the cervical zone and their extent posteriad in males and females consistent with prior studies among the ostertagiines (Lichtenfels et al., 1988; Hoberg et al., 1999). Transverse sections were hand cut with a cataract knife and mounted in glycerin jelly. Sections were used to examine structure and to count the number of ridges in a single male and female at the esophageal-intestinal junction (EIJ), one fourth, midbody, and three fourths of total body length as determined from the anterior. Sectioning was restricted to 2 specimens because of the limited number of worms that had been collected. Additional counts of ridges were based on reconstructions from wholemounted specimens.

The male specimens were evaluated on the basis of the copulatory bursa, spicules, and genital cone. Bursal ray patterns were determined and described using the system of Durette-Desset and Chabaud (1981) and Durette-Desset (1983). Papillae of the genital cone and rays of the bursa followed the numbering system of Chabaud et al. (1970). The structure of the ovejectors was evaluated based on recent definitions and descriptions among related nematodes (Lichtenfels et al., 2003). Owing to the difficulty in consistently discerning the division of the sphincter region $\mathrm{S} 2$ from the vestibule, the anterior and posterior portions of the vestibule, relative to the vulva, and adjacent portions of the sphincters (S1 and S2), were measured as a single unit. All measurements are given in micrometers, unless specified otherwise. In the description and tables the sample size $(n=)$ is followed by the range and mean $\pm 1 \mathrm{SD}$ in parentheses.

Taxonomy for hosts follows Wilson and Reeder (1993) in all text and tables. Host listings have been modified from those reported in the original literature to reflect current use and understanding of ungulate taxonomy.

\section{RESULTS}

Field collections for survey of helminth diversity in ungulates from eastern Africa revealed the occurrence of abomasal nematodes. Kob, and kongoni from the West Acholi District of Uganda, were found to be naturally infected with nematodes representing a previously undiagnosed genus and undescribed species of ostertagiine with a 2-1-2 bursal form.

\section{MORPHOLOGICAL DIAGNOSIS AND DESCRIPTION}

\section{Robustostrongylus gen. nov.}

Diagnosis: Ostertagiinae: Trichostrongyloidea. Small uncoiled nematodes with robust, stout body of large diameter, tapering bluntly in the cephalic and caudal extremities. Cephalic vesicle well developed. Synlophe bilaterally symmetric, with robust, knob-like ridges, parallel to slightly tapering in cervical region, extending to caudal extremity. Cervical papillae miniscule, thorn-like; along with excretory pore situated in posterior half of esophagus. Esophageal-intestinal valve prominent, bilobed, with constricted, muscularized ventriculus-like base. Males monomorphic. Bursal structure 2-1-2, symmetrical, membrane lacking cuticular bosses. Rays 2/3 parallel throughout length, Rays 3 massive with inflated tip relative to Rays 2; thickness of Rays 3 equal to or exceeding that of Rays 4. Rays 5/6 narrow, divergent distally. Accessory bursal membrane reduced containing widely spaced, divergent papillae "7." Rays 8 with massive bases, with distal tips curved mediad. Dorsal lobe laterally inflated, disposed ventrally to Rays 8 , containing reduced, narrow dorsal ray with distal bifurcation; branches terminating in Rays 9/10. Females amphidelphic with transverse vulva near $70 \%$ of
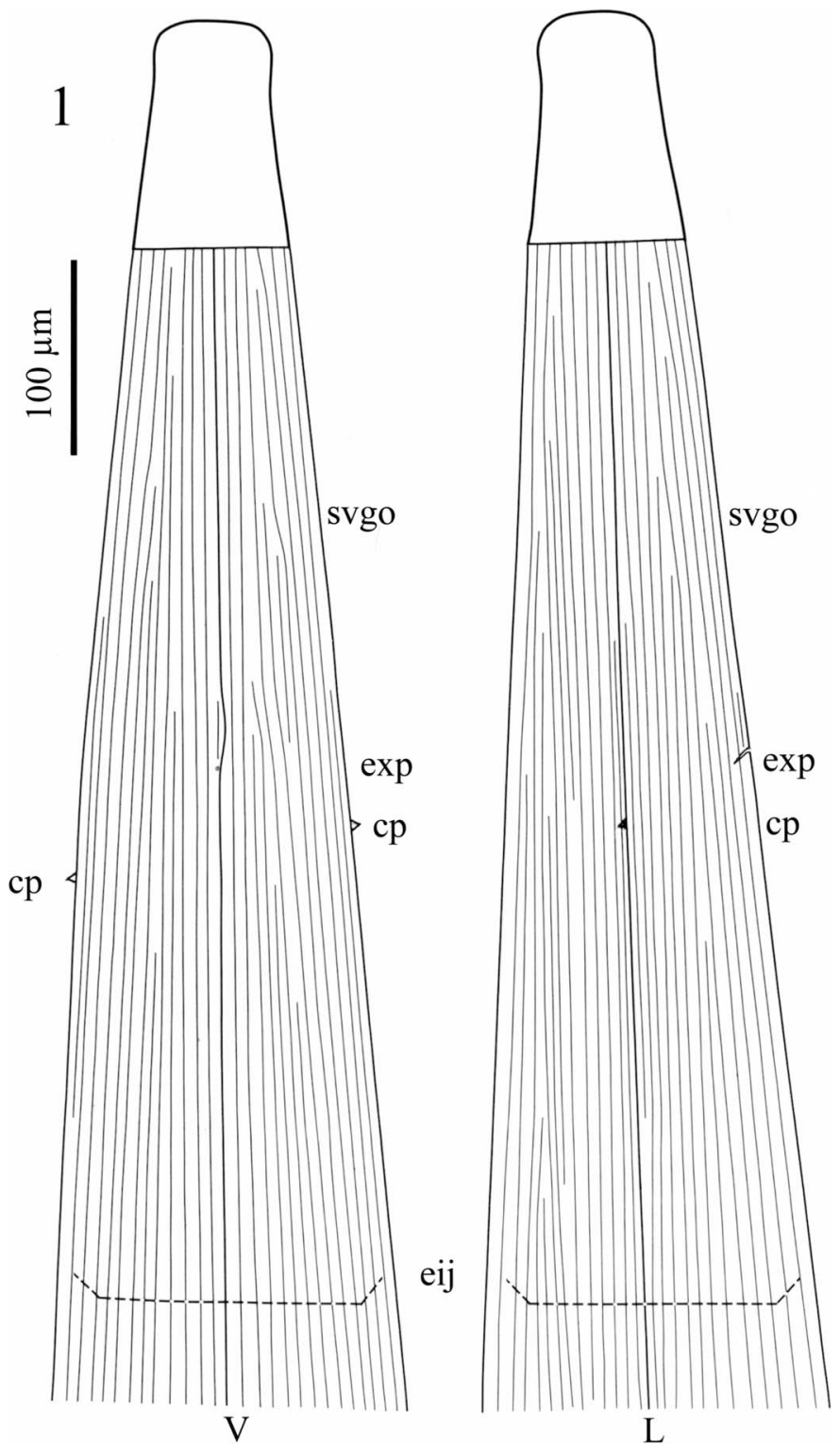

$\mathrm{L}$

FIGURE 1. Robustostrongylus aferensis gen. nov. et sp. nov., showing structure of synlophe in ventral (V) and lateral (L) views based on line drawings from a female paratype. Note parallel to weakly tapering pattern laterally, and positions of the orifices of the subventral glands (svgo), excretory pore (exp), cervical papillae (cp), and esophagealintestinal junction (eij).

body length from anterior, lacking cuticular fans or inflations; ovarian tracts highly convoluted, spiraled around intestine.

\section{Taxonomic summary}

Type species: Robustostrongylus aferensis gen. nov. et sp. nov.

Hosts: Kobus kob (Erxleben) (type) and kongoni or hartebeest, $A l$ celaphus buselaphus jacksoni (Pallas).

\section{Robustostrongylus aferensis sp. nov.} (Figs. 1-35)

General description: Trichostrongyloidea, uncoiled, straight, maximum diameter near midbody, 220 in males and 295 in females. Cephalic vesicle present as bipartite expansion; anterior-most portion strongly annulated. Cuticle with well-developed synlophe, lacking gradient, with perpendicular orientation; maximum number of ridges, 54, at esopha- 


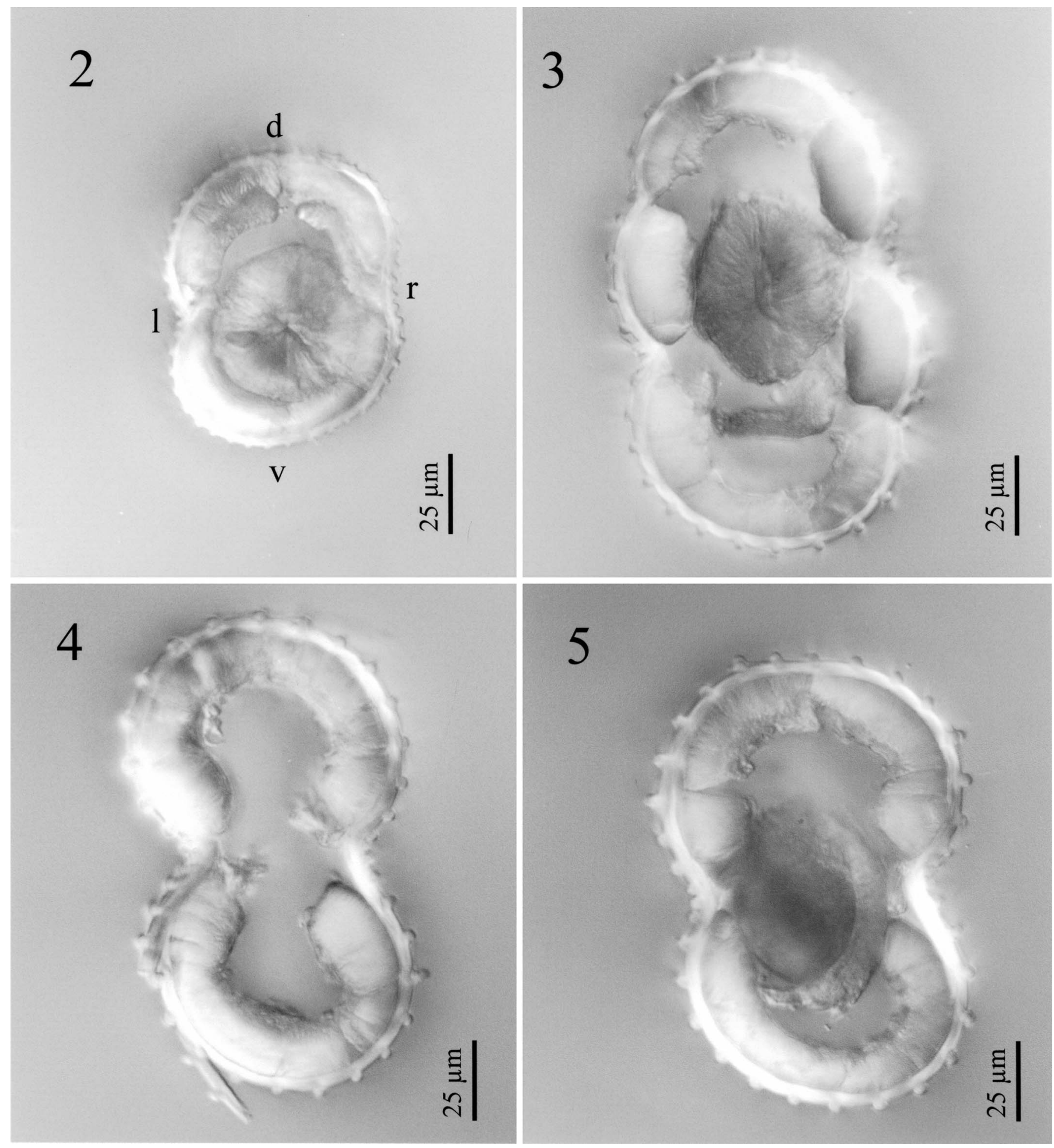

FIGURES 2-5. Robustostrongylus aferensis gen. nov. et sp. nov., showing structure of robust and knob-like synlophe based on photomicrographs of transverse sections of a male paratype; orientation is indicated as dorsal $=\mathrm{d}$, ventral $=\mathrm{v}$, left $=1$, and right $=\mathrm{r}$. (2) Synlophe at level of esophageal-intestinal junction showing 46 ridges. (3) Synlophe near termination of first quarter of body from anterior showing 38 ridges. (4) Synlophe at midbody showing 37 ridges. (5) Synlophe in posterior third quarter of body showing 36 ridges. 

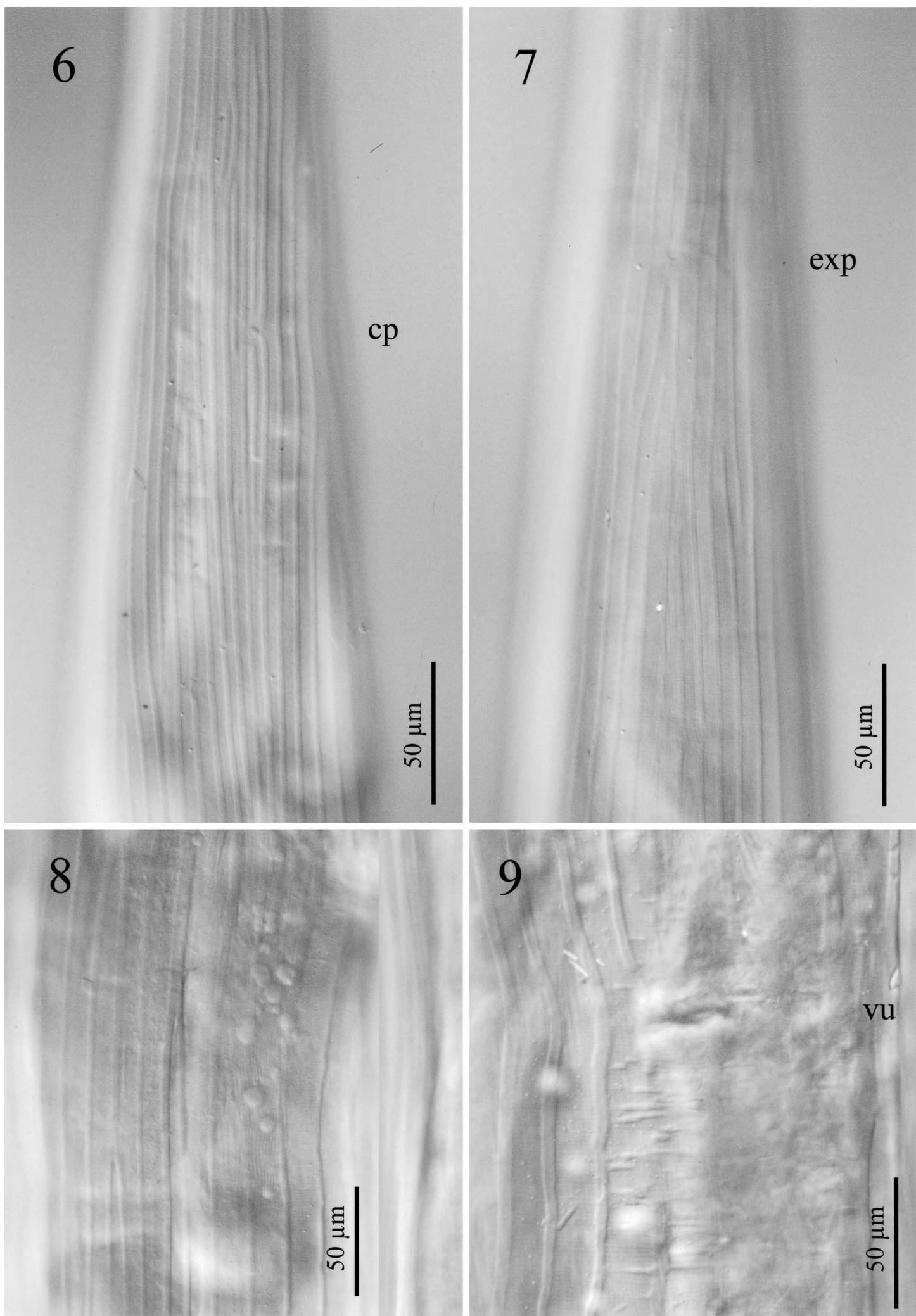

FIGURES 6-9. Robustostrongylus aferensis gen. nov. et sp. nov. showing structure of synlophe based on photomicrographs from entire specimens. (6) Cervical zone in right lateral view of female paratype showing parallel to weakly tapering pattern and position of the cervical papilla (cp). (7) Cervical zone in ventral view of male paratype showing position of excretory pore (exp) and crossover pattern in ventral ridges. (8) Synlophe in female paratype, right lateral view, showing robust structure of ridges in region posterior to vulva. (9) Transverse vulva (vu) in ventral view showing rugose cuticle and plate-like structure of synlophe. 


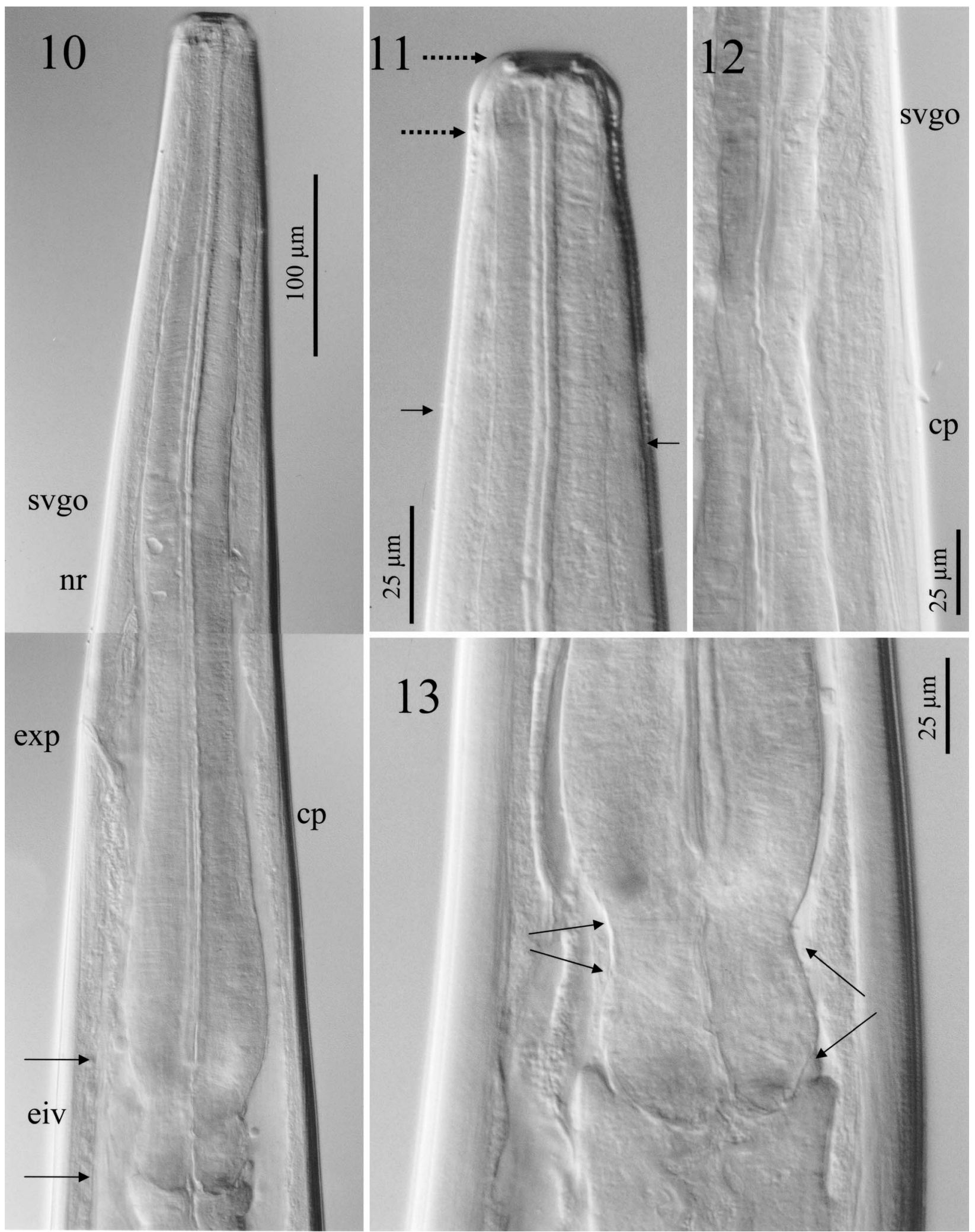

FIGURES 10-13. Robustostrongylus aferensis gen. nov. et sp. nov., cephalic and cervical structures based on photomicrographs as seen in male and female paratypes. (10) Anterior region of body in left lateral view of female, based on a composite of 2 micrographs, showing structure of esophagus, and positions of the orifices of the subventral glands (svgo), nerve ring (nr), excretory pore (exp), cervical papillae (cp) and constricted, bilobed esophageal-intestinal valve (eiv). (11) Cephalic extremity in left lateral view of male showing cephalic capsule (between dotted arrows) and asymmetrical extent of cephalic expansion (black arrows). (12) Cervical zone of male in ventral view showing miniscule, thorn-like cervical papilla (cp) and relative position of SVGO. (13) Basal esophagus of male in left lateral view showing constricted esophageal-intestinal valve and a band of strongly developed oblique musculature (arrows). 

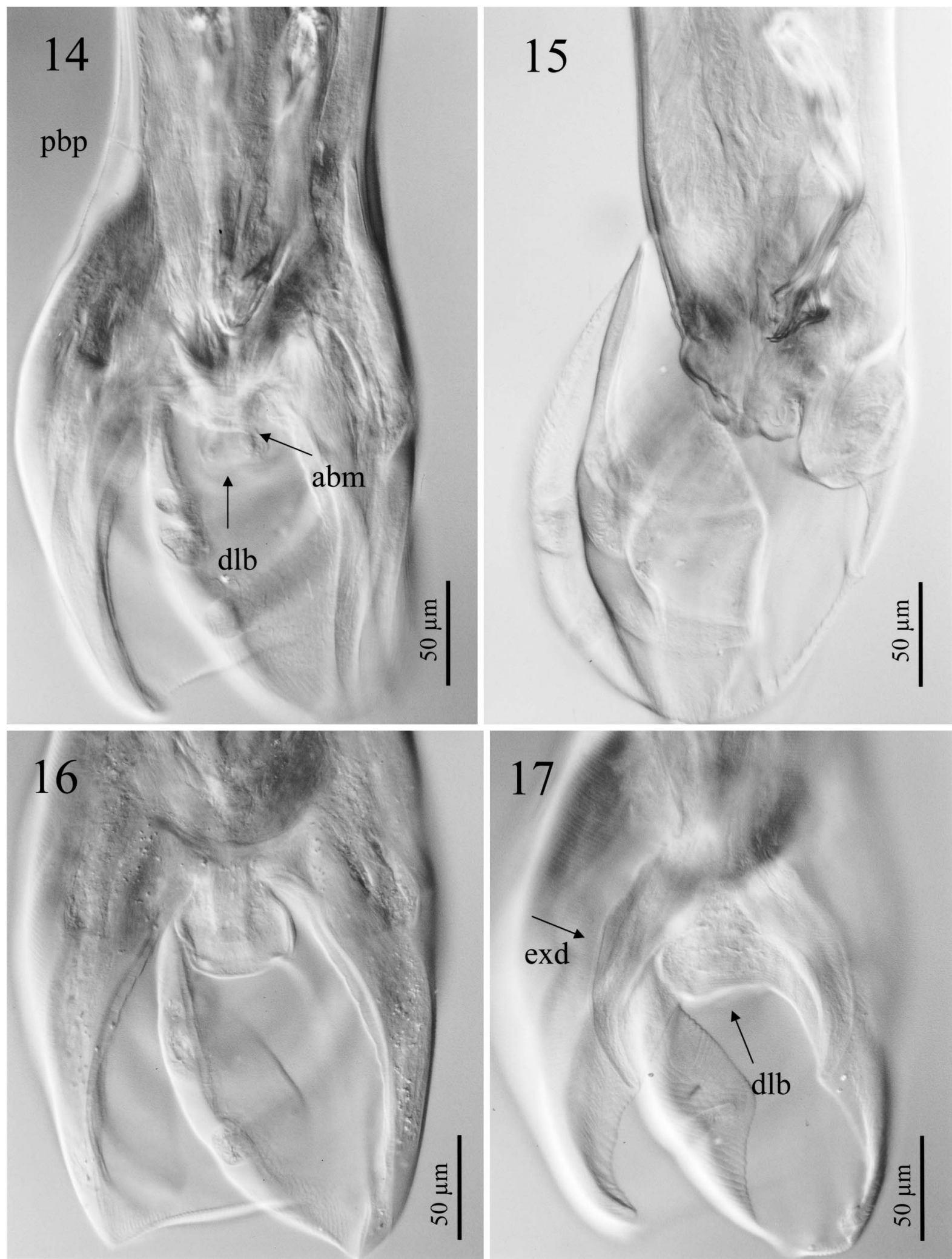

FIGURES 14-17. Robustostrongylus aferensis gen. nov. et sp. nov., showing structure of copulatory bursa in a male paratype based on photomicrographs. (14) Bursa in dorsal view, showing positons for prebursal papillae (pbp), accessory bursal membrane (abm), and dorsal lobe (dlb). (15) Bursa in left lateral view showing rounded and elongate bursal membrane, spicules with characteristic bend, genital cone and inflated dorsal lobe. (16) Dorsal lobe and narrow dorsal ray in dorsal view. (17) Dorsal lobe (dlb) showing rounded, inflated structure and position ventral to curved externodorsal rays (exd) or Rays 8. 


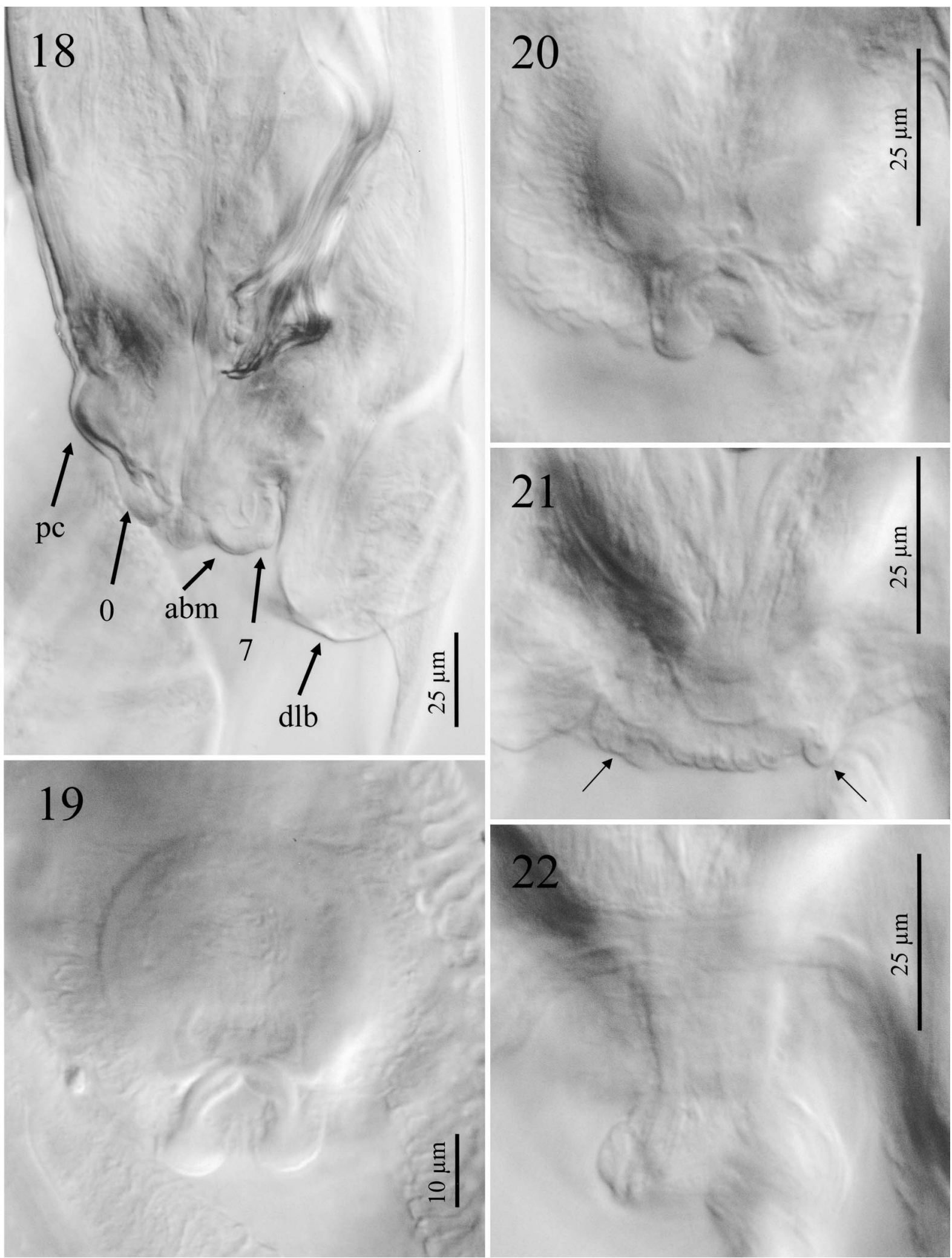

FIGURES 18-22. Robustostrongylus aferensis gen. nov. et sp. nov., showing structure of genital cone in male paratypes based on photomicrographs. (18) Genital cone in left lateral view showing weakly developed proconus (pc); "0" papillae (0); reduced, membranous accessory bursal membrane (abm); position of the 7 papillae (7) on the posterior margin of the abm; and an inflated dorsal lobe (dl). (19) Paired, arcuate " 0 " papillae terminating in bulbous expansions shown in ventral view; note plate-like structure of telmon supporting the cloaca. (20-22) Sequential views, from ventral to dorsal through genital cone, showing (20) position of arcuate " 0 " papillae; (21) structure of reduced and laterally expanded accessory bursal membrane and widely divergent 7 papillae (arrows); and (22) dorsal lobe, laterally inflated, containing relatively narrow dorsal ray or Rays $9 / 10$. 

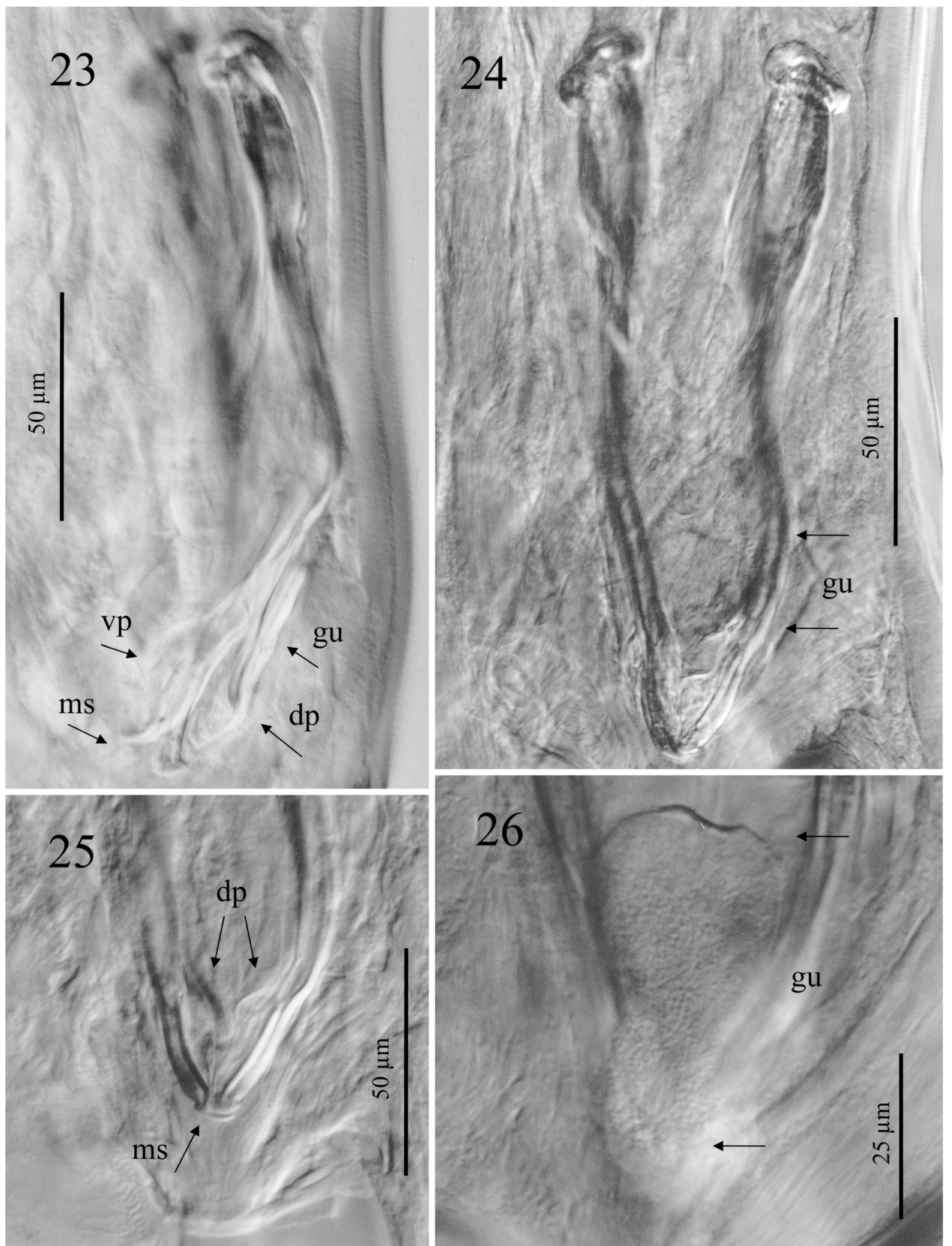

FIGURES 23-26. Robustostrongylus aferensis gen. nov. et sp. nov., showing structure of spicules and gubernaculum in male paratypes based on photomicrographs. (23) Spicules in left lateral view showing characteristic kinked or curved form, and positions and structure of the ventral process (vp), dorsal process (dp), and main shaft (ms); note the position and form of the weakly curved gubernaculum (gu) located dorsal to the spicules. (24) Spicules in dorsal view; note relative position for the head of the granular gubernaculum (gu, between arrows). (25) Spicule tips in dorsal view showing spatulate dorsal process $(\mathrm{dp})$ and main shaft $(\mathrm{ms})$ with hyaline foot. (26) Gubernaculum (gu) in dorsal view showing plate-like and weakly heart-shaped head (between arrows), and cryptic granular consistency. 


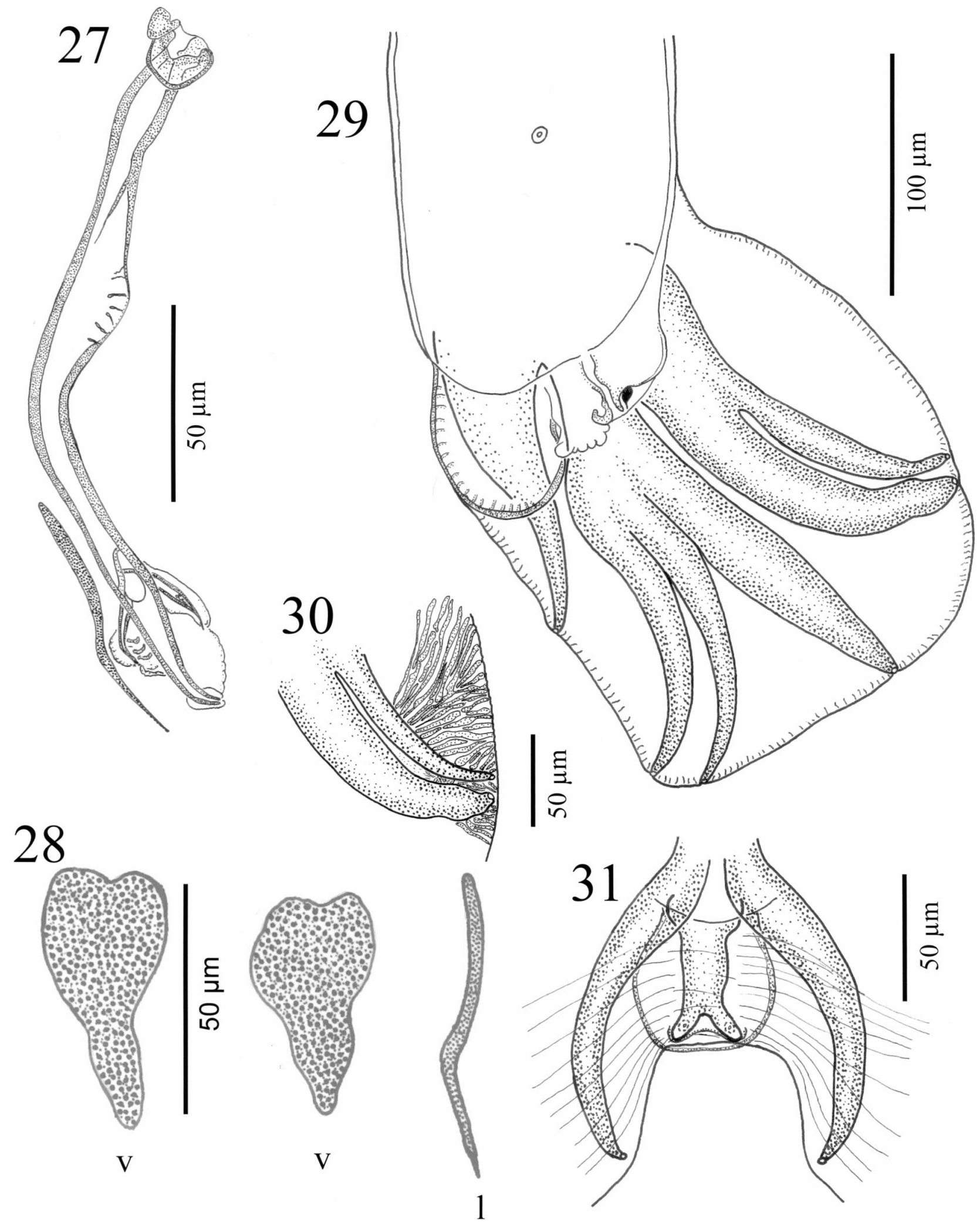

FIGURES 27-31. Robustostrongylus aferensis gen. nov. et sp. nov., showing structure of bursa, spicules, and gubernaculum in male holotype and paratypes based on line drawings. (27) Spicule and gubernaculum in paratype specimen, in right lateral view; note acutely pointed ventral and dorsal processes of equal length and series of membranes. (28) Gubernaculum in ventral (v) and lateral (1) views in holotype and paratype specimens. (29) Copulatory bursa of holotype in right lateral view showing left lobe and 2-1-2 pattern of lateral rays. Note robust Rays 3 with expanded tip attaining margin of bursal membrane, thick, elongate Rays 4, and ventral position of dorsal lobe. (30) Internal margin of bursal membrane (right lobe) at level of Rays 2 and Rays 3 showing vermicular ridges in holotype. (31) Dorsal lobe and ray in paratype specimen in dorsal view, showing relative positions and size of dorsal and externodorsal rays. 


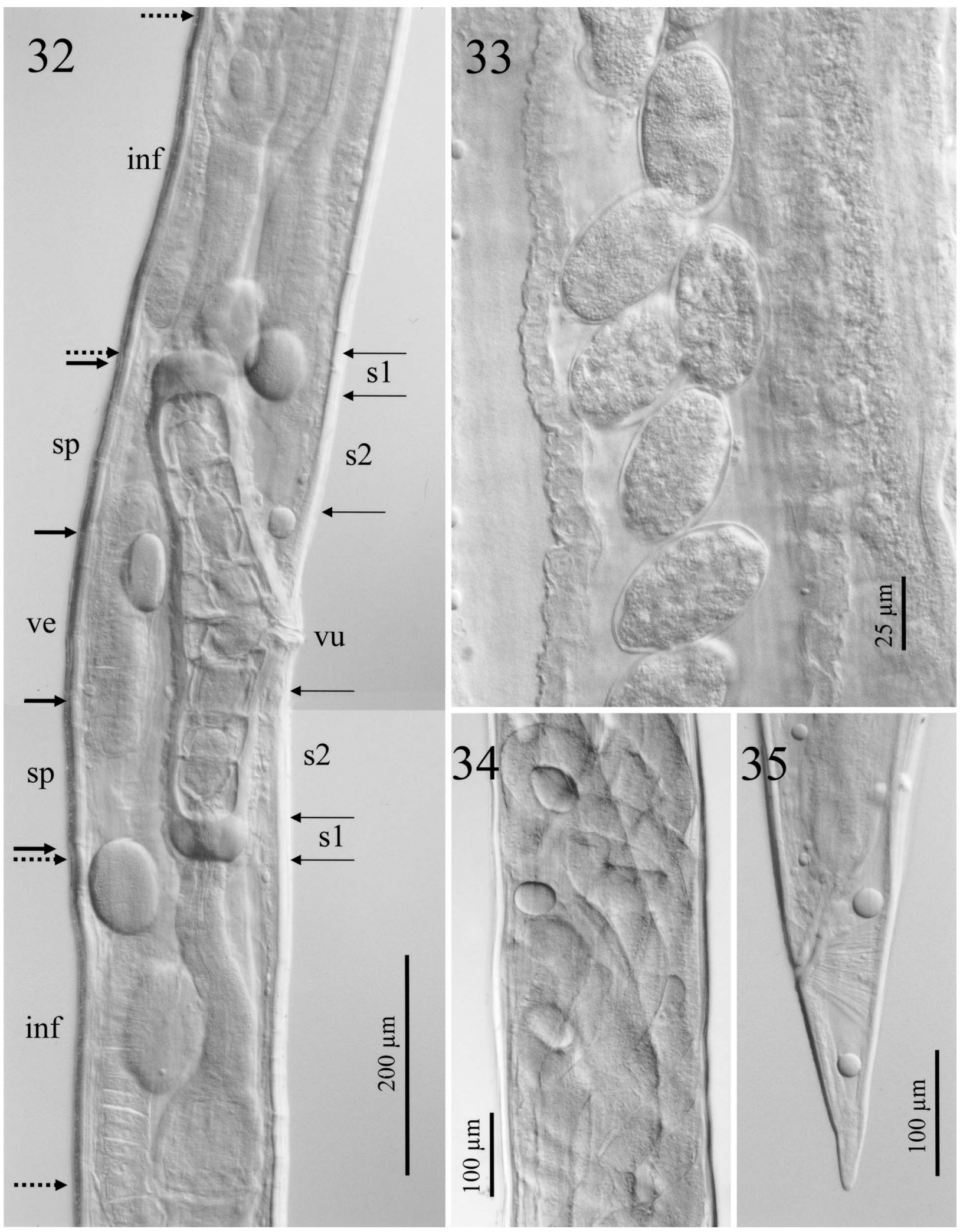

FIGURES 32-35. Robustostrongylus aferensis gen. nov. et sp. nov., showing characters of female allotype and paratype based on photomicrographs. (32) Ovejectors in allotype, composite image, in right lateral view showing structure of paired infundibula (inf), sphincters (sp) with bulblike sphincter 1 (s1) and tubular sphincter 2 (s2), vestibule (ve), and simple ventral vulva lacking inflations or ornamentation. (33) Eggs in utero, paratype. (34) Ovary in allotype, showing convoluted and spiraled structure in region anterior to midbody. (35) Tail in allotype showing robust and conical structure. 
geal-intestinal-junction (EIJ). Nerve ring (NR) and orifices of the subventral glands (SVGO) adjacent, in anterior third of cervical region. Cervical papillae (CP) miniscule, thorn-like, situated posterior to level of excretory pore (EXP). Position of CP and EXP substantially distal to SVGO, in posterior half of esophagus. Cuticular ornamentation at level of EXP lacking. Esophagus well developed, maximum diameter attained in slightly broadened, bulb-like base; esophageal-intestinal valve (EIV) prominent, bilobed, constricted, ventriculus-like, with oblique musculature. Males and females monomorphic.

Synlophe: Bilaterally symmetrical synlophe similar in males and females. Ridges notably robust, blunt, knob-like in transverse sections of body. Cervical zone $(n=6)$ with $24-30$ ridges extending to level of cephalic expansion increasing to $(n=7) 42-54$ ridges at EIJ. Laterally, cervical synlophe parallel in appearance, overall consistent with Type II pattern; in 8 of 22 lateral fields examined in 14 specimens, 1 ridge pair or partial ridge pair terminates in cervical region. 3-5 $(n=4)$ ridges continuous in each sub-lateraI/ventral field. CP adjacent to lateral-most ridge in right and left fields. Ventral/dorsal ridge systems parallel, consistent with Type A pattern; crossovers of ventral ridges present or absent. Lateral ridges $(n=6)$ and 5 of 6 dorsal-most ridges extend anteriad to level of cephalic expansion. In males and females, in anterior half of body posterior to cervical zone, ridges in lateral fields initially terminate sequentially adjacent to single lateral-most ridge ( $\mathrm{n}$ $=5) 46-54 \%(48 \pm 3 \%)$ and $29-38 \%(33 \pm 4 \%)$ of total length from anterior respectively. In midbody transverse sections ( 1 male and 1 female, respectively) 36 and 37 ridges; in third quarter, 36. In females synlophe extends to anus dorsal/ventrally, may extend beyond anus laterally. In males ridges terminate laterally at the prebursal papillae (PBP); dorsal/ventrally at 38-75 anterior to the PBP.

Male: Small nematodes with prominent copulatory bursa; discrete fields of bursal bosses lacking. Total length $(n=10) 6,438-7,560(6,957$ $\pm 368)$; maximum width $(\mathrm{n}=10) 165-220(194 \pm 16)$ attained at $34-$ $69 \%$ of body length measured from anterior; ratio of total body length: maximum width 1:34-39. Esophagus $(\mathrm{n}=10)$ 570-660 (616 \pm 28$)$ long; $8.1-9.9 \%$ of total body length. Valve at EIJ cylindrical, bilobed, ventriculus-like, longer than wide, $(n=10) 68-75(70 \pm 2)$ in length by $(\mathrm{n}=10) 52-65(58 \pm 4)$ in maximum width. Cephalic vesicle ( $\mathrm{n}$ $=8)$ 72-108 (91 \pm 10$)$. SVGO $(\mathrm{n}=10) 215-330(264 \pm 33)$, NR $(\mathrm{n}$ = 10) 232-298 (280 \pm 20$), \operatorname{EXP}(\mathrm{n}=10) 295-362(343 \pm 21)$, and $\mathrm{CP}(\mathrm{n}=10) 325-402(376 \pm 21)$ from cephalic extremity; position of EXP at 53-60\% and CP at 55-65\% of esophageal length from anterior. Copulatory bursa symmetrical, of type 2-1-2; lacking bosses, complex vermicular-ridges along margin on inner surface of bursal membrane. Rays $2 / 3$ curved, congruent along entire length, extending to margin of bursal membrane; Rays 3 massive relative to Rays 2, thickness of Rays 3 , with expanded distal tip, equal to or exceeding that of Rays 4. Rays $5 / 6$ narrow, parallel throughout length, gradually divergent distally. Rays 8, slight, curved dorsally, extending to margin of bursa. Dorsal ray narrow with parallel margins, relatively short $(\mathrm{n}=8) 42-48(44 \pm$ 2) with initial bifurcation $(n=7) 67-76 \%$ of total length from base. Papillae " $9 / 10$ " on bifurcate distal tips of dorsal ray. Dorsal lobe reduced, laterally inflated, substantially exceeds width of dorsal ray; disposed ventrally to Rays 8 . Genital cone with weakly developed proconus; prominent, arcuate, paired " 0 " papillae with bulbous distal expansions positioned posterior to proconus on ventral aspect of cloaca. Accessory bursal membrane (ABM) inconspicuous in dorso-ventral view; reduced in length, laterally expanded with delicate papilliform margin and widely divergent, filamentous papillae "7." Cloaca with telamon and cuticularized support structures surrounding orifice. Spicules equal in length $(\mathrm{n}=10)$ 162-178 $(171 \pm 5)$ with trifurcation 78 $82 \%$ of total length from anterior. In lateral view, spicules narrow and filamentous, strongly curved, with bend at mid-length. Dorsal and ventral processes of spicules near equal length; dorsal process simple, spatulate in dorso-ventral view, weakly curved in lateral view, tapering to acute point; ventral process straight, with bend near acutely pointed, narrow, distal tip; main shaft tapering to blunt point, with weakly developed hyaline foot. Well-developed membranes envelop all processes of spicules. Gubernaculum cryptic, shield-like, weakly heart-shaped, strongly granular in dorsal/ventral view, tapering distally, maximum width $(\mathrm{n}=5) 25-26(25 \pm 0.4)$; laterally with pronounced bend anterior to distal tip, total length $(\mathrm{n}=5)$ 50-61 (52 \pm 2$)$.

Female: Small nematodes lacking prominent cuticular ornamentation other than synlophe. Total length $(\mathrm{n}=10) 8,585-11,107(9,969 \pm 748)$; maximum width $(\mathrm{n}=10) 248-295(275 \pm 14)$ attained $29-67 \%$ of body length measured from anterior; ratio of total body length:maximum width 1:32-40. Cephalic vesicle $(\mathrm{n}=10) 82-112(100 \pm 11)$. Esophagus $(\mathrm{n}=10) 595-750(672 \pm 45)$ long; $6.1-7.5 \%(6.8 \pm 0.5)$ of total body length. Valve at EIJ, ventriculus-like, bilobed, $(\mathrm{n}=11) 70-82(77$ \pm 3 ) long, $(\mathrm{n}=11) 62-72(68 \pm 3)$ in maximum width. SVGO $(\mathrm{n}=$ 8) 258-308 (282 \pm 16$), \mathrm{NR}(\mathrm{n}=10) 258-338(301 \pm 21)$, EXP $(\mathrm{n}=$ 9) 342-392 (371 \pm 16$)$, and $\mathrm{CP}(\mathrm{n}=10) 358-442(404 \pm 26)$ from cephalic extremity; position of EXP at $51-60 \%$ and CP at $54-68 \%$ of esophageal length from anterior. Ovaries didelphic, amphidelphic, strongly convoluted, spiraled around intestine. Vulva opens as ventral transverse slit $(\mathrm{n}=10) 68-75 \%(72 \pm 2.0)$ of body length from anterior; cuticular inflations and fans absent; synlophe modified as platelike structures posterior to vulva. Perivulvar pores bilateral, located postero-lateral to vulva in subventral fields. Anterior infundibulum $(\mathrm{n}=$ 11) 262-345 (299 \pm 27$)$, anterior sphincter and vestibule, including $S 1$ and $\mathrm{S} 2$, $(\mathrm{n}=11)$ 170-300 (238 \pm 38$)$. Posterior infundibulum $(\mathrm{n}=$ 11) 250-302 (282 \pm 18$)$, posterior sphincter and vestibule, including S1 and S2, $(\mathrm{n}=11) 180-248(216 \pm 21)$; length of anterior vestibule $>$ posterior vestibule. Total ovejector length $(\mathrm{n}=11) 938-1,137(1,036$ $\pm 67)$. Eggs ovoid, with thin shell, $(n=60$ in 6 specimens) $51-80$ (62 $\pm 12)$ long by $30-42(36 \pm 7)$ wide; oriented in single or double rows in anterior and posterior uterine limbs. Tail conical $(\mathrm{n}=11) 132-218$ $(172 \pm 21)$, bluntly rounded at caudal extremity, with weak annulations present distal to synlophe termination.

\section{Taxonomic summary}

Host: Kobus kob (Erxleben), type host. Other recognized hosts include kongoni or hartebeest, Alcelaphus buselaphus jacksoni (Pallas).

Locality: Type locality: In type host from West Acholi District, Uganda; ca. $02^{\circ} 45^{\prime} \mathrm{N}, 032^{\circ} 10^{\prime} \mathrm{E}$. Currently unknown from other localities.

Specimens: Holotype male, USNPC 100,000 and allotype female, USNPC 100,001 in type host from type locality. Paratypes from type locality include (1) USNPC 66320, 8 males and 8 females in $K$. kob; and (2) USNPC 66321, 2 female nematodes in A. b. jacksoni. One male voucher in $K$. kob was excluded from the type series because it was damaged; originally under USNPC 66320, it is now under USNPC 100,002 .

Etymology: Robustostrongylus is a compound name derived from the Latin "robustus" for strong or robust and the Greek "strongylus" denoting a roundworm. The species "aferensis" is derived from the Latin "afer" for African. Thus, R. aferensis for a robust, cigar-like nematode from Africa.

\section{Remarks}

Affiliation of Robustostrongylus gen. nov. within the Ostertagiinae, is based on putative synapomorphies for the subfamily. Attributes which diagnose a relationship within the ostertagiines include trifurcate spicules with a characteristic ostertagiine window (Figs. 15, 23, 24, 27), paired "0" papillae (Figs. 19, 20), a simple accessory bursal membrane (Figs. 18, 21, 29), and a prominent, elongate, esophageal valve (Figs. 10, 13) (Hoberg and Abrams, 2007; Hoberg, Abrams, and Ezenwa, 2008). Although the ABM and EIV are modified in Robustostrongylus, these attributes remain consistent with the general structure seen among other ostertagiines. These putative synapomorphies for the ostertagiines are established relative to sister-taxa represented by the Haemonchinae (e.g., species of Haemonchus Cobb, 1898, Mecistocirrus Railliet et Henry, 1912, Ashworthius Le Roux, 1930) and species of Graphidium Railliet et Henry, 1909 as identified in prior analyses (Hoberg and Lichtenfels, 1994; Durette Desset et al., 1999).

A suite of unique characters for $R$. aferensis gen. nov. et $\mathrm{sp}$. nov. relative to all ostertagiine genera is demonstrated in males and females by a posterior position for the EXP and $\mathrm{CP}$ (in the posterior $50 \%$ of esophageal length from the anterior and substantially distal to the SVGO) (Figs. 1, 10), a ventriculus-like, constricted and bilobed EIV with prominent oblique musculature (Figs. 10, 13), robust, domed or knob-like ridges comprising the synlophe (Figs. 2-9), a maximum number of ridges attained near the EIJ, the exceptionally large midbody diameter relative to length (e.g., in females, length:width $=1: 32-40$ ), and in females, the anterior position of the vulva (near $70 \%$ from the anterior extremity) and absence of cuticular inflations adjacent to the vulva (Figs. 8, 9, 32). Among all other ostertagiines across 14 genera, 
the CP and EXP are always near the SVGO and in the anterior half of the esophagus; the valve at the EIJ is cylindrical, never bilobed or constricted and lacks strongly developed oblique musculature; the synlophe is composed of narrow acutely pointed ridges, and where known, the numbers of ridges increase posteriad to the EIJ usually attaining a maximum near the middle third of body length, the midbody is narrow and not strongly inflated (in females, length:width $=1: 58-107$ ), the position of the vulva is always $>80 \%$ of body length from the anterior, and cuticular inflations at the vulva are present in species of some genera. Based on these criteria, specimens of Robustostrongylus are unequivocally distinct from nematodes representing all known genera of the subfamily.

Specimens of Robustostrongylus further contrast with the haemonchines, the putative sister-group for the Ostertagiinae, and closely related species of Graphidium with respect to the synlophe, cephalic, esophageal and cervical characters and in the position of the vulva and structure of the " 0 " papillae (Figs. 1-13, 18-20, 32). Among haemonchines, the EXP and CP are situated in the anterior half of the esophagus, a prominent valve is lacking at the junction with the intestine, and the vulva is located near $80 \%$ of body length from the anterior and there is a single " 0 " papilla. Relative to Robustostrongylus, the ridges of the synlophe are acutely pointed with patterns and distribution differing considerably in the Haemonchinae (Lichtenfels and Pilitt, 2000; Hoberg et al., 2002). Among species of Graphidium, although the CP and EXP are positioned from mid-length into the posterior region of the esophagus, a weakly developed, ovoid valve joins the esophagus and intestine, the synlophe ridges are acutely pointed, the vulva (often with a copulatory plug) is situated near $74-85 \%$ of body length, and there is a single " 0 " papilla. Midbody diameter for haemonchines (length: width ratio $=1: 30-54$, mean $=1: 45$ among 6 species) and $\mathrm{Gra}$ phidium strigosum (1:28-44) overlaps with that for Robustostrongylus but not with other taxa within the Ostertagiinae.

Among the ostertagiines, specimens of $R$. aferensis are immediately distinguished from nematodes in 8 genera where the lateral rays of the bursa are disposed in the 2-2-1 pattern (Fig. 29) (Africanastrongylus, Cervicaprastrongylus, Hamulonema, Hyostrongylus, Mazamastrongylus, Sarwaria, Spiculopteragia, and Teladorsagia) (Durette-Desset, 1983; Hoberg, Abrams, and Ezenwa, 2008; Hoberg and Abrams, 2008). Among 6 remaining genera in which a 2-1-2 bursal pattern is characteristic (Camelostrongylus, Longistrongylus, Marshallagia, Orloffia, Ostertagia, and Pseudomarshallagia), specimens of $R$. aferensis are distinguished, respectively, among these taxa by a broader suite of structural characters in addition to those previously outlined (Figs. 1-35).

Polymorphism for males is apparently not demonstrated in Robus tostrongylus, Camelostrongylus, Longistrongylus, and Pseudomarshallagia; this conclusion is based on prior examinations of ostertagiine diversity (Hoberg and Abrams, 2008; Hoberg, Abrams, and Ezenwa, 2008). Specimens of $R$. aferensis contrast with those of the monotypic C. mentulatus (Railliet and Henry, 1909) (Figs. 1-5, 18, 21, 23-27) in which males of the latter are characterized by the extreme length and unique ornamented structure of the spicules, strongly cuticularized gubernaculum, absence of a proconus, fused "7" papillae that diverge distally, a membranous $\mathrm{ABM}$, and a dorsal lobe positioned dorsally to Rays 8.

Only 1 male of $P$. elongata was available for study. Based on this specimen and on the redescriptions (Graber and Delavenay, 1978; Gibbons, 1981a) and as illustrated by Gibbons and Khalil (1982), in $P$. elongata the spicules are broad and thick in dorso-ventral view, and the alate main shaft is trifurcate near the distal end with the tips enveloped in a series of complex membranes. The dorsal ray and lobe are inflated and broad proximally, with a pronounced taper towards the distal end; the robust but reduced dorsal lobe is situated in a position dorsal to the externodorsal rays or Rays 8 . These characters serve to distinguish male specimens of $R$. aferensis from the monotypic $P$. elongata.

Robustostrongylus aferensis contrasts with Marshallagia, Orloffia, and Ostertagia in the absence of polymorphism among males; comparisons outlined here are in the context of major morphotypes for the 3 latter genera (see Dróżdż, 1995). Robustostrongylus further differs from Marshallagia based on the exceptionally long dorsal ray, filamentous " 0 " papillae, elongate filamentous " 7 " papillae contained in a delicate ABM, relatively massive spicules, and absence of a gubernaculum and proconus among males and the large dimensions for eggs among females that characterize species of the later genus. A reduced and inflated dorsal lobe and ray disposed ventrally to Rays 8 (Figs. 14-17, 31), reduced and laterally expanded ABM (Figs. 14, 21), arcuate structure of the " 0 " papillae (Figs. 19, 20), strongly curved or kinked spicules and a granular gubernaculum (Figs. 23, 26-28) distinguish $R$. aferensis from species of both Orloffia and Ostertagia; in addition, a proconus is lacking in species of Orloffia.

Robustostrongylus aferensis seems most similar to species of Longistrongylus based on the reduced ABM; inflated dorsal lobe containing a relatively narrow dorsal ray, which bifurcates distally; the arcuate " 0 " papillae that terminate in bulbous expansions; and thin, narrow spicules that in some species have a characteristic bend near mid-length (Figs. 14-27) (E. P. Hoberg and A. Abrams, unpubl. obs.). The original description of L. meyeri (type species) and diagnosis of the genus Longistrongylus was based on male and female specimens of large dimensions (Le Roux, 1931). Maximum width of females for L. meyeri is reported as $437 \mu \mathrm{m}$; however, the length:width ratio (1:58-64) calculated from measurements for individual females in the original description (and from specimens attributed to this species and examined during the current study) is typical but at the lower range of variation among other ostertagiines; the CP and EXP are both in the anterior half of the esophagus. Le Roux (1931) described males and females as "rather long and thin," which differs substantially from the robust body form seen in specimens of $R$. aferensis. The valve at the EIJ for $L$. meyeri was described as "not well developed," and the figure of the cervical region showed the esophagus lacking any basal constriction, a character consistent among all species of Longistrongylus (Le Roux, 1931; Yeh, 1956; Gibbons, 1977; E. P. Hoberg and A. Abrams, unpubl. obs.). Females were described as having ovarian tracks that spiraled around the intestine in a manner similar to that typical for some haemonchines. This pattern does not seem usual among other species now relegated to Longistrongylus. In type and voucher specimens attributed to L. meyeri that were examined during the present study (E. P. Hoberg and A. Abrams, unpubl. obs.), the ovarian tracks were weakly spiraled around the intestine, but not strongly convoluted; the disposition of the ovarian tracks was not addressed in redescriptions by Yeh (1956) or Gibbons (1977). Specimens of $R$. aferensis further differ from $L$. meyeri in the details of the spicules and copulatory bursa, presence of a proconus, position of Rays 8 , the terminal bifurcation of the dorsal ray, and genital cone including structure and position of papillae "7" and the ABM (Le Roux, 1931; Gibbons, 1977). Finally, in all species of Longistrongylus the dorsal lobe remains dorsal to Rays 8 , the bursa contains numerous and discrete fields of bosses, and irregular cuticular inflations occur at the level of the vulva (Gibbons, 1977; Hoberg et al., 1993; Hoberg, Abrams, and Ezenwa, 2008).

These attributes are in addition to the suite of characters that are distinct at the generic level among the ostertagiines, and as a consequence Longistrongylus cannot be simply emended to accommodate Robustostrongylus. Resurrection of either Kobusinema Ortlepp, 1963 or Bigalkenema Ortlepp, 1963 for $R$. aferensis, both correctly reduced as synonyms of Longistrongylus by Gibbons (1977), also is not supported. Although $R$. aferensis can be readily distinguished from all species of Longistrongylus, it is apparent that these genera are likely to be closely related and may be sister-groups.

Gibbons (1977) noted broad morphological variation among specimens attributed to L. schrenki in species of Kobus from Uganda and Tanzania. These included some female nematodes in which the maximum width attained 288 (males at 216), and in which the EXP and CP were situated in the posterior half of the esophagus. Additionally, the position of the vulva in some specimens (e.g., in Kobus kob from Uganda) is at $68-72 \%$ of body length from the anterior extremity. The ratio of total body length:maximum width could not be accurately calculated for these specimens, and there are no data for the structure of the synlophe, esophageal valve, or ovarian tracks. In contrast, for specimens representing $L$. schrenki, otherwise consistent with descriptions and redescriptions for this species (and other species of Longistrongylus available to us during the current study) (Table I), the CP and EXP were in the anterior half of the esophagus, the length-to-width ratio ranged from 1:58-104, and the vulva was located between 82 and $85 \%$ of body length from the anterior. Consequently, it seems possible that some specimens relegated to L. schrenki in the revision by Gibbons (1977) may be attributable to Robustostrongylus and that the redescription of this species may have been a composite. At a minimum, this may include some female and male specimens in Kobus kob from Uganda, 
and male specimens in Kobus sp. and Kobus vardoni (Livingstone) from Tanzania (see Gibbons, 1977 for critical meristic data).

\section{DISCUSSION}

Robustostrongylus aferensis gen. nov. et sp. nov. represents a new ostertagiine, among those with a 2-1-2 bursal pattern, in which males are monomorphic. Assessment of distribution, diversity, and records of occurrence for ostertagiines across Africa (summarized in Hoberg and Abrams, 2008; Hoberg, Abrams, and Ezenwa, 2008) suggests the absence of polymorphism among males of $R$. aferensis as defined for this subfamily (e.g., Dróżdż, 1995). Across the global ostertagiine fauna, monomorphic males are known from 4 of 7 genera where a 21-2 bursal pattern is characteristic (Camelostrongylus, Longistrongylus, Pseudomarshallagia, and Robustostrongylus) and from 6 of 8 genera defined by a 2-2-1 bursal formula (Africanastrongylus, Cervicaprastrongylus, Hamulonema, Hyostrongylus, Mazamastrongylus, and Sarwaria) (Hoberg and Abrams, 2008). Interestingly, polymorphism seems to be most often manifested among ostertagiines with distributions in the Palearctic and across the Holarctic, i.e., Marshallagia, Orloffia, Ostertagia, Spiculopteragia, and Teladorsagia. Perhaps this reflects an environmental component (temperature or humidity) in the origins and drivers that serve to maintain the balanced polymorphism for structurally discrete males among species that characterize these primarily northern or high-latitude genera (Hoberg and Abrams, 2008; Hoberg, Polley et al., 2008).

Globally, ostertagiine faunas and more generally those of gastrointestinal nematodes in ungulates are defined by an intricate mosaic structure composed of endemic and introduced species (Hoberg et al., 1999; Hoberg, Polley et al., 2008). Among ostertagiines, there are 15 genera in the global fauna, with 5 being endemic to Africa (Africanastrongylus, Hamulonema, Longistrongylus, Pseudomarshallagia, and Robustostrongylus); although generic-level endemism is high, there are relatively few species limited solely to Africa (Hoberg, Abrams, and Ezenwa, 2008). There are 26 species partitioned in 10 genera that occur in African mammals and, among these, 22 species in 8 genera are endemic (Hoberg and Abrams, 2008; Hoberg, Abrams, and Ezenwa, 2008). Among those occurring in freeranging ungulates, most genera are monotypic, but highly discrete morphologically, including Africanastrongylus (1 species), Hamulonema (2), Longistrongylus (8), Pseudomarshallagia (1), and Robustostrongylus (1). Also, 9 endemic species are known among Ostertagia (5), Cervicaprastrongylus (2), and Hyostrongylus (2), and, for the latter 2 genera, distributions encompass some non-ungulate hosts such as lagomorphs and primates, respectively (Hoberg, Abrams, and Ezenwa, 2008). In contrast, non-endemics, primarily associated with introduced and domestic ungulates, represent species that are geographically widespread around the globe, including Hyostrongylus (1), Marshallagia (1), Ostertagia (1), and Teladorsagia (1). The center of diversity for the ostertagiines is outside of the African region, although this continent has been significant in the radiation of this nematode fauna (Daubney, 1933; Hoberg, Abrams, and Ezenwa, 2008).

Endemism in the contemporary fauna may be an indicator of the temporal duration and degree of isolation of ostertagiines and other gastrointestinal nematodes among African ungulates (Hoberg et al., 2004). Among the Cooperiinae, another related subfamily among the trichostrongyloids, there are both a high number of endemic genera (5 of 8, including Cooperioides Daubney, 1933; Impalaia Mönnig, 1923; Megacooperia Khalil and Gibbons, 1976; Minutostrongylus Le Roux, 1936; and Ortleppstrongylus Durette-Desset, 1970) and some taxa, particularly Cooperia Ranson, 1907, that contain numerous endemic species primarily associated with bovids as hosts (Gibbons 1978, 1981b; Gibbons and Khalil, 1982; Khalil and Gibbons, 1976; Durette-Desset, 1983; Hoberg and Lichtenfels, 1994; Durette-Desset et al., 1999). Haemonchinae (specifically Ashworthius, Haemonchus, and Leiperiatus Sandground, 1930) diversified in large part in association with ungulates in Africa (Gibbons, 1979; Hoberg et al., 2004) and collectively with Cooperiinae must be regarded as a strongly tropical-adapted fauna (Hoberg, Abrams, and Ezenwa, 2008).

Parallel radiations in Africa are postulated for some ostertagiines, cooperines, and haemonchines, although it is not clear whether periods of diversification across these disparate nematode taxa and their artiodactyl hosts were congruent on spatial and temporal scales (Hoberg et al., 2004; Marcot, 2007; Hoberg, Abrams, and Ezenwa, 2008). Diversification in Haemonchus was associated with successive waves or episodes of biotic expansion by ungulates from Eurasia into Africa and sequential host switching by nematodes extending since the Miocene (Hoberg et al., 2004). Radiation among parasite groups coincided with periods of ecological perturbation and variation in climate which influenced ecological structure for artiodactyl faunas in Africa during the late Tertiary (Vrba, 1985, 1995; Vrba and Schaller, 2000). Host switching beyond ungulates is also seen among the Cooperiinae (in Bathyergidae for Ortleppstrongylus; in Lagomorpha for some Impalaia) and also among Ostertagiinae (Cervicaprastrongylus in Lagomorpha; Hyostrongylus in Pongidae) in Africa. Such distributions are indicative of colonization events involving mammalian groups occupying habitat and in sympatry with artiodactyls, and ecological structure promoting host switching (Hoberg and Brooks, 2008).

Geographic and host colonization are emerging as primary mechanisms involved in diversification of complex host-parasite assemblages (Hoberg and Brooks, 2008). Ecological perturbation driven by episodic variation in climate was an important determinant for biotic expansion, isolation, and development of faunal associations across sub-Saharan Africa since the Miocene. These processes that have functioned in evolutionary time continue to be manifested in shallow ecological time where a breakdown in ecological isolation leads to expansion of invasive species and emergence of disease in contemporary systems involving both free-ranging and domestic ungulates (Hoberg, 1997; Brooks and Hoberg, 2006, 2007). Tropical-adapted faunas, including haemonchines, cooperiines, and some ostertagiines have been introduced or translocated with ungulate hosts around the world. In temperate to boreal latitudes, current regimes for global warming and alteration in precipitation are predicted to be associated with novel patterns of host and geographic associations for this fauna, potentially driving the emergence of disease (Hoberg, Polley et al., 2008). Thus, knowledge of biodiversity extending from species to population structure is critical, particularly when explored in the context of historical determinants that may either limit or serve to promote expansion by an array of pathogens into new geographic settings and host groups. 


\section{ACKNOWLEDGMENTS}

We gratefully acknowledge Lynda Gibbons and Mark T. Fox at the Royal Veterinary College, London, U.K., and Eileen Harris at the Natural History Museum, London, U.K., for assistance in providing specimens and information on various species of Longistrongylus and $P$. elongata that were critical for our study. Furthermore, we thank Joop Boomker from the Department of Veterinary Tropical Diseases, University of Pretoria, South Africa, for discussion and insight about the African ostertagiine fauna.

\section{LITERATURE CITED}

ANDREEVA, N. K. 1956. Revizia ostertagieii (trikhostrongilid) zhvachnykh. Trudy Instituta Veterinarri, Kazakhskii Filiala Vsesoyuznoi. Sel'skokhozyaistvennykh Nauk 8: 473-487.

BRooks, D. R., AND E. P. Hoberg. 2000. Triage for the biosphere: The need and rationale for taxonomic inventories and phylogenetic studies of parasites. Comparative Parasitology 68: 1-25.

$\longrightarrow$, AND $\longrightarrow$ 2006. Systematics and emerging infectious diseases: From management to solution. Journal of Parasitology 92: 426-429.

, AND - 2007. How will climate change affect parasitehost-assemblages? Trends in Parasitology 23: 571-574

Chabaud, A. G., F. Puylaert, O. Bain, A. J. Petter, and M.-C. DurETTE-DESSET. 1970. Remarques sur l'homologie entre les papilles cloacales des Rhabdites et les côtes dorsales des Strongylida. Comptes Rendus Hebdomadaire des Séances de l'Academie des Sciences, Paris 271: 1771-1774.

Criscione, C. D., R. Poulin, And M. S. Blouin. 2005. Molecular ecology of parasites: Elucidating ecological and microevolutionary processes. Molecular Ecology 14: 2247-2257.

Daubney, R. 1933. Trichostrongylid nematodes from sheep in Kenya. Parasitology 25: 224-241.

DRóżDż, J. 1965. Studies on helminths and helminthiasis in Cervidae. I. Revision of the subfamily Ostertagiinae Sarwar, 1956 and an attempt to explain the phylogenesis of its representatives. Acta Parasitologica Polonica 13: 455-481.

1995. Polymorphism in the Ostertagiinae Lopez-Neyra, 1947 and comments on the systematics of these nematodes. Systematic Parasitology 32: 91-99.

DuRETte-Desset, M.-C. 1982. Sur les divisions génériques des Nématodes Ostertagiinae. Annales de Parasitologie Humaine et Comparée 57: $375-381$.

1983. Keys to the genera of the superfamily Trichostrongyloidea, Vol. 10. In $\mathrm{CIH}$ keys to the nematode parasites of vertebrates, R. C. Anderson and A. G. Chabaud (eds.). Commonwealth Agricultural Bureaux, Farnham Royal, U.K., 86 p.

- 1989. Nomenclature proposée pour les espèces décrites dans la sous-famille des Ostertagiinae Lopez-Neyra, 1947. Annales de Parasitologie Humaine et Comparée 64: 356-373.

, AND A. G. Chabaud. 1981. Nouvel essai de classification des Nématodes Trichostrongyloidea. Annales Parasitologie Humaine et Comparée 56: 297-312.

- J. P. Hugot, P. Darlu, and A. G. Chabuad. 1999. A cladistic analysis of the Trichostrongyloidea (Nematoda). International Journal for Parasitology 29: 1065-1086.

GibBons, L. M. 1974. Recent records of nematodes in East African mammals. Helminthological Abstracts Series A 43: 641-646.

- 1977. Revision of the genera Longistrongylus Le Roux 1931. Kobusinema Ortlepp, 1963 and Bigalkenema Ortlepp, 1963 (Nematoda: Trichostrongylidae). Journal of Helminthology 51: 41-62.

1978. Revision of the genus Cooperioides Daubney, 1933 (Nematoda: Trichostrongylidae). Journal of Helminthology 52: 311-322.

. 1979. Revision of the genus Haemonchus Cobb, 1898 (Nematoda: Trichostrongylidae) Systematic Parasitology 1: 3-24.

- 1981a. The taxonomic position of the nematode species Pseudomarshallagia thalae (Troncy and Graber, 1973) Graber and Delavenay, 1978 (family Trichostrongylidae). Systematic Parasitology 2: $217-218$.

- 1981b. Revision of the African species of the genus Cooperia
Ransom, 1907 (Nematoda: Trichostrongylidae) Systematic Parasitology 2: 219-252.

, AND L. F. KHALIL. 1982. A key for the identification of genera of the nematode family Trichostrongylidae Leiper, 1912. Journal of Helminthology 56: 185-233.

Graber, M., And R. Delavenay. 1978. Pseudomarshallagia elongata Roetti, 1941 (Nematoda: Trichostrongylidae), parasite de la caillette des petits ruminants d'Ethiopia. Revue d'Èlevage et de Médecine Vétérinaire des Pays Tropicaux 31: 353-359.

Grillo, V., F. Jackson, J. Cabaret, and J. S. Gilleard. 2007. Population genetic analysis of the ovine parasitic nematode Teladorsagia circumcincta and evidence for a cryptic species. International Journal for Parasitology 37: 435-447.

Haigh, J. C., C. Mackintosh, ANd F. GRifFin. 2002. Viral, parasitic and prion diseases of farmed deer and bison. Office International des Épizooties Revue Scientifique et Technique 21: 219-248.

HobERG, E. P. 1997. Parasite biodiversity and emerging pathogens: A role for systematics in limiting impacts on genetic resources. In Global genetic resources: Access, ownership and intellectual property rights, K. E. Hoaglund and A. Y. Rossman (eds.). Association of Systematics Collections, Washington, D.C., p. 71-83.

, AND A. AbRAms. 2007. Emended description and redetermination of Sarwaria caballeroi $\mathrm{n}$. comb. (Nematoda: Ostertagiinae) with details of the synlophe and esophageal characters. Journal of Parasitology 93: 1140-1150. , AND - 2008. Hamulonema gen. nov. for Teladorsagia hamata and Ostertagia kenyensis in the ostertagiine fauna (Nematoda: Trichostrongyloidea) from African ungulates. Journal of Parasitology 94: 866-879.

$\longrightarrow,-$ R. A. Carenno, and J. R. Lichtenfels. 2002. Ashworthius patriciapilittae $\mathrm{n}$. sp. (Trichostrongyloidea: Haemonchinae), an abomasal nematode in Odocoileus virginianus from Costa Rica, and a new record for species of the genus in the Western Hemisphere. Journal of Parasitology 88: 1187-1199.

,- , AND V. O. EzENWA. 2008. An exploration of diversity among the Ostertagiinae (Nematoda: Trichostrongyloidea) in ungulates from Sub-Saharan Africa with a proposal for a new genus. Journal of Parasitology 94: 230-251.

—, AND D. R. BROOKS. 2008. A macroevolutionary mosaic: Episodic host switching, geographic colonization and diversification in complex host-parasite systems. Journal of Biogeography 35: 15331550 .

- A. A. KocAn, AND L. G. Rickard. 2001. Gastrointestinal strongyles in wild ruminants. In Parasitic diseases of wild mammals, W. Samuel, M. Pybus, and A. A. Kocan (eds.). Iowa State University Press, Ames, Iowa, p. 193-227.

, AND J. R. Lichtenfels. 1994. Phylogenetic systematic analysis of the Trichostrongylidae (Nematoda), with an initial assessment of coevolution and biogeography. Journal of Parasitology 80: 976996.

- $\longrightarrow$, AND L. GibBons. 2004. Phylogeny for species of Haemonchus (Nematoda: Trichostrongyloidea): Considerations of their evolutionary history and global biogeography among Camelidae and Pecora (Artiodactyla). Journal of Parasitology 90: 1085-1102. , $\longrightarrow$ AND P. A. PilitT. 1993. Synlophe of Cooperia neitzi (Trichostrongylidae: Cooperiinae) with comments on vulval inflations and hypertrophy of cuticular ridges among the trichostrongylids. Journal of the Helminthological Society of Washington 60: 153-161.

, K. J. Monsen, S. KutZ, and M. S. Blouin. 1999. Structure, biodiversity, and historical biogeography of nematode faunas in Holarctic ruminants: Morphological and molecular diagnoses for Teladorsagia boreoarcticus n. sp. (Nematoda: Ostertagiinae) a dimorphic cryptic species in muskoxen. Journal of Parasitology 85: 910-934.

, L. Polley, E. J. Jenkins, And S. J. Kutz. 2008. Pathogens of domestic and free-ranging ungulates: Global climate change in temperate to boreal latitudes across North America. Office International des Épizooties Revue Scientifique et Technique 27: 511-528.

JANSEN, J. 1989. A concise history of the Ostertagiinae Lopez-Neyra, 1947 (Nematoda: Trichostrongylidae) and a discussion on its composition. Acta Leidensia 58: 151-159.

KhaliL, L. F., AND L. M. GibBons. 1976. The helminth parasites of suni, 
Nesotragus moschatus von Dueben, 1846 from Kenya with the description of a new genus and two new species of nematodes (Vermes). Revue Zoologie Africa 90: 559-577.

Le Roux, P. L. 1931. On Longistrongylus meyeri gen. and sp. nov., a trichostrongyle parasitizing the Red Hartebeest Bubalis caama. Journal of Helminthology 9: 141-146.

Leignel, V., J. Cabaret, And J. F. Humbert. 2002. New molecular evidence that Teladorsagia circumcincta is a species complex. Journal of Parasitology 88: 135-140.

Lichtenfels, J. R., And P. A. Pilitt. 2000. Synlophe patterns of the Haemonchinae of ruminants (Nematoda: Trichostrongyloidea). Journal of Parasitology 86: 1093-1098.

-, AND L. M. GibBOnS. 2003. Ovejector structure in the Haemonchinae (Nematoda: Trichostrongyloidea) of ruminants. Journal of Parasitology 89: 984-993.

- $\longrightarrow$, AND M. B. LANCASTER. 1988. Cuticular ridge patterns of seven species of Ostertagiinae (Nematoda) parasitic in domestic ruminants. Proceedings of the Helminthological Society of Washington 55: 77-86.

Marcot, J. D. 2007. Molecular phylogeny of terrestrial artiodactyls. In The evolution of artiodactyls, D. R. Prothero and S. E. Foss (eds.). Johns Hopkins University Press, Baltimore, Maryland, p. 4-18.

MönNIG, H. O. 1932. Wild antelopes as carriers of nematode parasites of domestic ruminants-Part II. 18th Annual Report of the Director of Veterinary Services and Animal Industry, Union of South Africa, Onderstepoort, South Africa, p. 155-172.

Round, M. C. 1962. The helminth parasites of domesticated animals in Kenya. Journal of Helminthology 36: 375-449.

- 1968. Check list of the helminth parasites of African mammals.
Technical Communication No. 38. Commonwealth Agricultural Bureaux, Farnham Royal, Bucks, U.K., 252 p.

SACHS, R., AND C. SACHS. 1968. A survey of parasitic infestation of wild herbivores in the Serengeti region in northern Tazania and the lake Rukwa region in southern Tanzania. Bulletin of Epizootic Diseases of Africa 16: 455-472.

Skrjabin, K. I., N. P. Shikobalova, And R. S. Shults. 1954. Essentials of Nematodology III. Trichostrongylids of animals and man. Academy of Sciences of the USSR, Moscow.

Travassos, L. P. 1937. Revisão da familia Trichostrongylidae Leiper, 1912. Institute Oswaldo Cruz Monographs 1: 1-512.

VRBA, E. S. 1985. African Bovidae: Evolutionary events since the Miocene. South African Journal of Science 81: 263-266.

. 1995. The fossil record of African antelopes (Mammalia: Bovidae) in relation to human evolution and paleoclimate. In Paleoclimate and evolution with emphasis on human origins, E. S. Vrba, G. S. Denton, T. C. Partridge, and L. H. Burkle (eds.). Yale University Press, New Haven, Connecticut, p. 385-424.

, AND G. B. Schaller. 2000. Phylogeny of the Bovidae based on behavior, glands, skulls, and postcrania. In Antelopes, deer and relatives: Fossil record, behavioral ecology, systematics and conservation, E. S. Vrba and G. B. Schaller (eds.). Yale University Press, New Haven, Connecticut, p. 203-202.

Wilson, D. E., AND D. M. REEDER. 1993. Mammals species of the world. A taxonomic and geographic reference. Smithsonian Institution Press, Washington, D.C., 1207 p.

YEH, L. S. 1956. On a collection of helminths from Thomson's gazelle, Gazella thomsoni, from Tanganyika. Journal of Helminthology 29: 203-228. 